\title{
Kekerasan Terhadap Jurnalis oleh Oknum Aparat Kepolisian Saat Meliput Aksi Demonstrasi Di JakartaTahun 2019-2020
}

\author{
${ }^{1}$ Fathurahman Saleh, ${ }^{2}$ Bilal Sukarno \\ Program Studi Ilmu Politik, UPN Veteran Jakarta \\ fathurahmans@upnvj.ac.id, bilals@upnvj.ac.id
}

\begin{abstract}
Abstraksi
Negara dengan sistem demokrasi yang biasanya menitikberatkan pada kebebasan, paling sedikit memiliki 2 (dua) unsur kebebasan yang secara umum digambarkan, yaitu kebebasan berekspresi dan kebebasan pers. Kebebasan pers di negara demokrasi dapat dijadikan sebagai indikator untuk mengukur demokratis tidaknya suatu negara. Jurnalis sebagai elemen terpenting dalam pers atau media, seringkali menghadapi berbagai bentuk kekerasan yang dilakukan oleh berbagai elemen masyarakat, salah satunya berasal dari oknum adalah kepolisian. Kekerasan terhadap jurnalis oleh oknum kepolisian, kerap terjadi saat jurnalis meliput aksi demonstrasi yang terjadi di berbagai daerah di Indonesia. Penelitian ini bertujuan untuk melihat bentuk dan dasar dari kebebasan pers di Indonesia, serta mengidentifikasi tindakan kekerasan yang dialami jurnalis oleh oknum aparatpihak kepolisian Republik Indonesia, saat meliput aksi demonstrasi yang terjadi di Jakarta dalam kurun waktu 2019-2020. Penelitian ini bersifat menggunakan metode penelitian kualitatif deskriptif, dengan teknik pengumpulan data menggunakan metode studidengan pendekatan kepustakaan yang bersumber pada buku, jurnal ilmiah, artikel, serta berbagai literatur lain yang menunjang data penelitian. Adapun hasil penelitian ini berkesimpulan bahwa bentuk pers di Indonesia termasuk dalam bentuk Social Responsibility Theory yang mengharuskan pers memberikan informasi yang aktual dan mengedukasi. Namun ketika jurnalis meliput berita untuk menghimpun informasi, hambatan ditemui dengan kehadiran oknum anggota kepolisian yang melakukan tindak kekerasan terhadap jurnalis, khususnya saat meliput aksi demonstrasi yang terjadi di DKI Jakarta pada Tahun 2019-2020 karena alasan tidak terima yang berujung pada pengrusakan hasil liputan, menghapus, serta kerap menggunakan kekerasan. Penulis juga menyajikan dua sudut pandang dari kedua belah pihak dimana kepolisian memandang jurnalis tidak adil dengan peliputan yang terjadi, dan disisi lain jurnalis, media dan pers menganggap kepolisian menggunakan kekerasan terhadap jurnalis untuk menghilangkan bukti kekerasan.
\end{abstract}

Kata Kunci: Kebebasan Pers, Kekerasan Terhadap Jurnalis, Oknum Kepolisian, Demonstrasi.

\begin{abstract}
A country with a democratic system that usually focuses on freedom, has at least 2 (two) elements of freedom that are generally described, namely freedom of expression and freedom of the press. Freedom of the press in a democratic country can be used as an indicator to measure the democratic or not of a country. Journalists as the most important element in the press or media, often face various forms of violence committed by various elements of society, one of which comes from the police. Violence against journalists by police officers, often occurs when journalists cover demonstrations that take place in various regions in Indnesia. This study aims to look at the form and basis of press freedom in Indonesia, as well as identify acts of violence experienced by journalists by police officers of the Republic of Indonesia, while covering the demonstrations that took place in Jakarta in the period 2019-2020. This research is qualitative descriptive, with data collection techniques using
\end{abstract}


literature study methods sourced in books, scientific journals, articles, and various other literature that supports research data. The results of this study concluded that the form of press in Indonesia is included in the form of Social Responsibility Theory that requires the press to provide actual information and educate. However, when journalists cover the news to gather information, obstacles are encountered by the presence of police officers who commit acts of violence against journalists, especially when covering demonstrations that occurred in DKI Jakarta in 2019-2020 for reasons of not accepting that led to the destruction of coverage results, delete, and often use violence. The author also presents two points of view from both sides where the police view journalists unfairly with the coverage that occurred, and on the other hand journalists, media and press consider the police to use violence against journalists to eliminate evidence of violence.

Keywords: Freedom of The Press, Violence Against Journalists, Police, Demonstration.

\section{Pendahuluan}

Kemerdekaan atas informasi melalui media cetak dan elektronik, maupun kebebasan atas ruang gerak pers, memang sudah seharusnya dijamin dalam negara demokrasi. Hal tersebut dapat menunjukan sebuah negara dapat dikatakan demokratis atau tidak. Media atau pers, kerap dianggap sebagai institusi yang mempunyai kekuatan besar dalam mempengaruhi pikiran masyarakat di suatu negara. Tidak heran, jika institusi ini sering disebut sebagai lembaga keempat atau the fourth estate, setelah lembaga eksekutif, legislatif, dan yudikatif.

Meski demikian yang harus kita ketahui bersama ialah, adanya perbedaan bentuk dari media atau pers dalam suatu negara. Bentuknya antara lain adalah Pers Otoriter, Pers Libertarian, Pers Tanggung Jawab Sosial, dan Pers Totaliter. Masing-masing bentuk tersebut, mempunyai fungsi dan tujuan yang berbeda serta kebaikan dan keburukannya masing-masing. Terlepas dari hal tersebut, tentu saja kembali lagi kepada fungsi umum pers atau media ialah menggambarkan realitas atas kondisi yang terjadi di tengah masyarakat serta menyebarluaskannya se-objektif mungkin, meskipun ada beberapa teori yang menggambarkan media sebagai institusi yang kerap mempengaruhi apa yang dipikirkan masyarakatnya.

Negara Indonesia yang menganut sistem demokrasi, mulai menerapkan unsur-unsur demokrasi salah satunya yaitu keterbukaan atas informasi melalui media cetak maupun elektronik dan kebebasan pers yang mana sebelum 1998, kebebasan dan kemerdekaan pers di cengkram erat oleh Presiden Soeharto dengan kedok landasan Pers Pancasila yang dinilai cenderung merujuk kepada jurang otoritarian. Transformasi yang hadir pada lingkungan perpolitikan akibat proses Reformasi 1998 tersebut, turut berdampak signifikan terhadap kebebasan pers di Indonesia, salah satunya ditunjukan dengan hadirnya UU yang dinilai lebih menjunjung tinggi dan memperhatikan kebebasan pers di Indonesia. Peraturan tentang pers yang semula diatur dalam UU No. 21 Tahun 1982 Tentang Ketentuan-Ketentuan Pokok Pers, berubah menjadi UU No. 40 Tahun 1999 Tentang Pers, yang mana lebih memberi angin segar terhadap ruang gerak pers di Indonesia. Hal tersebut tidak lain dan tidak bukan merupakan hasil dari unjuk rasa atau demonstrasi besar-besaran yang terjadi di berbagai daerah dan awam disebut sebagai Aksi Reformasi 1998, yang 
beragenda besar untuk megakhiri era otoritarian Soeharto (Saptohadi, 2011, hal. 128129)(Saptohadi, 2011, hal. 128-129).

Walaupun semenjak Reformasi, pers menjadi lebih bebas bergerak dalam menghimpun dan memberikan informasi, bukan berarti pers atau media tidak menemui hambatan-hambatannya yang lain dalam proses menjalan tugasnya tersebut sampai pada hari ini. Jurnalis ${ }_{2}$ yang bertugas untuk mencari dan menghimpun berita mengenai kondisi sosial, politik, maupun budaya yang terjadi di berbagai daerah di Indonesia, tidak jarang kerap menerima berbagai bentuk kekerasan, seperti intimidasi lisan, pengusiran dan pelarangan liputan, perusakan alat atau hasil liputan, bahkan kekerasan fisik. Berdasarkan laporan Aliansi Jurnalis Independen (AJI), terhitung sejak Januari sampai dengan 2019 Desember 2019, sampai dengan Desember 2020, setidaknya terdapat 1583 kasus kekerasan terhadap jurnalis, dengan 102 kasus diantaranya disebabkan oleh oknum aparat kepolisian saat jurnalis sedang meliput aksi demonstrasi yang terjadi di Jakarta (Aliansi Jurnalis Independen, 2021)(Aliansi Jurnalis Independen, 2021).

LBH pers juga merilis sebuah laporan data kekerasan terhadap jurnalis, dimana kekerasan paling tinggi terhadap wartawan terjadi pada tahun 2020, dimenangkan oleh pihak kepolisian sebagai posisi pertama, atas perlakuan tindak kekerasan terhadap jurnalis. Dalam Annual Report LBH Pers Tahun 2020, menjelaskan bahwa sejak 1 Januari sampai 10 Desember 2020, terdapat 117 kasus kekerasan terhadap jurnalis yang menurut mereka naik secara signifikan sebesar 32\%, dibandingkan dengan tahun 2019 yaitu sebanyak 79 kasus. Sebanyak 76 dari total 117 kasus tersebut, menunjukan bahwa kepolisian masih menduduki posisi pertama sebagai pihak yang paling sering melayangkan kekerasan terhadap jurnalis, dan 71 dari 76 kasus tersebut dilayangkan pihak kepolisian saat jurnalis sedang meliput aksi demonstrasi atas pengesahan Omnibus Law pada Oktober 2020 kemarin.

Kasus kekerasan yang terjadi dalam kurun waktu 2019-2020 berdasarkan data diatas, ditemukan bahwa aksi demonstrasi besar merupakan arena bagi oknum aparat anggota kepolisian untuk melayangkan berbagai bentuk kekerasan terhadap jurnalis. Jika kita ingin melihat waktu kebelakang, setidaknya ada beberapa kali aksi demonstrasi besar yang terjadi di berbagai daerah di Indonesia yang diawali dengan Demonstrasi didepan gedung Bawaslu, Jakarta Pusat pada 22 Mei 2019, Aksi Reformasi Dikorupsi pada 24-30 September 2019, serta Aksi Demonstrasi Tolak RUU Ciptaker Omnibus Law pada Oktober 2020 kemarin.

Adapun penelitian terdahulu yang sudah meneliti mengenai topik kekerasan terhadap jurnalis oleh oknum kepolisian yakni penelitian yang berjudul "Implementasi Perlindungan Hukum Bagi Wartawan Korban Kekerasan Yang Dilakukan Oleh Kepolisian”, karya Hariardo Haloho dan Arie Steven pada 2016 silam. Dengan berfokus kepada aspek perlindungan hukum bagi wartawan yang menerima tindak kekerasan dari kepolisian, penelitian tersebut berkesimpulan bahwa implementasi perlindungan hukum bagi wartawan belum efektif, dikarenakan masih maraknya perlindungan kepolisian terhadap anggotanya yang melakukan tindak kekerasan terhadap jurnalis, dengan sengaja memperlambat proses penyelidikan. Wewenang Diskresi yang dimiliki anggota kepolisian karena berdasar pada UU No. 2 Tahun 2002 tentang Kepolisian Negara Republik Indonesia, juga dapat menjadi faktor kesewenang-wenangan tindakan kekerasan yang dilakukan oknum kepolisian terhadap para jurnalis, karena dalam UU tersebut secara eksplisit menyebutkan anggota kepolisian dapat melaksanakan tugas dan wewenang menurut penilaiannya sendiri, apabila 
dihadapkan dalam keadaan yang mendesak, untuk tujuan menjaga dan memelihara kemanan. Berkaca dari hal tersebut, sudah saatnya kita untuk merefleksikan kembali segala unsurunsur demokratis yang ada di Indonesia, salah satunya mengenai kebebasan pers di Indonesia yang pada realitanya menemui banyak sekali bentuk kekerasan yang diterima para jurnalis, meskipun segala peraturan yang terkait dengan kebebasan pers telah diatur dalam UU No. 40 Tahun 1999.

Penelitian ini berbeda dengan penilitian terdahulu, jika penelitian sebelumnya berfokus pada aspek penjaminan hukum bagi wartawan yang menerima tindak kekerasan dari oknum kepolisian, penelitian ini lebih berfokus untuk melihat bentuk serta dasar kebebasan pers di Indonesia, serta mengidentifikasi tindakan kekerasan yang dialami jurnalis oleh oknum anggota pihak kepolisian saat meliput aksi demonstrasi yang terjadi di Jakarta dalam kurun waktu 2019-2020, karena ditahun-tahun tersebutlah pergolakan politik dalam negeri terjadi besar-besaran akibat ketidakpuasan berbagai elemen masyarakat terhadap kebijakan yang dikeluarkan oleh pejabat pemerintah, yang ditunjukan dengan aksi demonstrasi di beberapa titik daerah di Indonesia. Namun, bukan berarti penelitian terdahulu tidak begitu saja dilewatkan oleh penulis, karena penelitian terdahulu tersebut juga bermanfaat terhadap penulis sebagai sumber rujukan karena masih memiliki korelasi dengan fokus yang penulis angkat dalam penelitian ini.

Dengan menggunakan metode penelitian studi kepustakaan atau library research yang bersifat kualitatif dengan berdasar pada penelusuran melalui berbagai sumber literatur seperti buku, jurnal, artikel, dan literatur lain yang menunjang peneliti untuk merampungkan jurnal ini, maka peneliti berharap dapat menjawab beberapa pertanyaan yang muncul dalam jurnal ini yang diantaranya sebagai berikut; 1) Apa bentuk pers serta landasan kebebasan pers di Indonesia pasca Reformasi?: 2) Mengapa jurnalis kerap mengalami tindak kekerasan oleh oknum kepolisian saat sedang meliput aksi demonstrasi di Jakarta pada Tahun 20192020?: 3) Bagaimana konsep kebebasan pers di Indonesia dilihat dari dua sudut pandang yang berbeda?kedua pihak menanggapi fenomena ini?

\section{Metode}

Penulis menggunakan metode penelitian studi kepustakaan atau library research dimana menurut Zed (2004), studi kepustakaan merupakan serangkaian kegiatan yang berkenaan dengan metode pengumpulan data pustaka, membaca, dan mencatat serta mengolah bahan peneilitian (Zed, 2004: 3). Menurutnya pula, studi kepustakaan mempunyai beberapa ciri utama yang diantaranya sebagai berikut; (i) peneliti berhadapan langsung dengan teks atau naskah; (ii) data pustaka bersifat ready to use; (iii) data pustaka umumnya merupakan sumber sekunder yang berarti data penelitian diperoleh dari tangan kedua; dan yang terakhir (iv) konidisi data pustaka tidak dibatasi ruang dan waktu yang artinya data tersebut tidak akan berubah karena tersimpan dalam bentuk tetulis.

Dengan begitu, penulis tidak secara langsung terjun ke lapangan, namun mengandalkan data-data yang bersumber dari buku, jurnal ilmiah, artikel yang kredibel, peraturan undang-undang, serta literatur lain yang mendukung rampungnya jurnal ini. Pencarian data menggunakan mesin pencarian (search engine) google scholar karena dianggap ilmiah dan bisa dipertanggung jawabkan. Data-data yang telah diperoleh tersebut, kemudian dianalisis oleh penulis dan digunakan penulis untuk mendukung argumen serta 
pemikiran penulis untuk menjawab dan menjelaskan hubungan serta keterkaitan tentang topik yang diangkat, dan akan dituangkan penulis pada bagian pembahasan. Penulis berharap agar tulisan ini dapat dijadikan referensi bagi para akademisi yang mempunyai latar belakang yang sama seperti penulis, maupun digunakan untuk sekedar menambah pengetahuan mengenai kekerasan terhadap jurnalis oleh oknum kepolisian saat aksi demonstrasi.

\section{Hasil dan Pembahasan.}

\section{Empat Teori Pers (Four Theories Of The Press)}

Teori yang menjadi landasan peneliti gunakan untuk membantu menjelaskan mengenai bentuk media atau pers di suatu negara adalah 4 Teori Pers atau (Four Theories of The Press) yang digagas oleh Fred. S. Siebert, Wilburm Scharm, dan Theodore Peterson yang diperkenalkan secara luas pada Tahun 1956 (Triyono, 2013, hal. 194). Teori ini sengaja digunakan penulis dengan dasar bahwa, jika kita dapat mengkategorikan bentuk pers di Indonesia berdasarkan dengan teori 4 bentuk pers, dapat meningkatkan probabilitas melihat kecenderungan gerak pers di Indonesia yang juga menuntun kita untuk mengetahui mengapa oknum anggota kepolisian kerap melayangkan tindak kekerasan terhdap jurnalis. Ada kemungkinan kita dapat menelusuri lebih jauh mengenai hal-hal apa saja yang menjadi kemungkinan oknum kepolisian melayangkan tindak kekerasan tersebut kepada jurnalis, karena arah gerakan pers di Indonesia sesuai dengan bentuk pers yang telah dikategorikan oleh Siebert, Scharm, dan Peterson.

Dalam 4 Teori Pers, Siebert, Scharm, dan Peterson membagi pers kedalam 4 bentuk, yaitu Pers Otoritarian, Pers Libertarian, Pers Tangggung Jawab Sosial, dan Pers Totalitarian.

Pers Otoritarian (Authoritarianism Media Theory), identik dengan kontrol segala bentuk komunikasi oleh penguasa yang dalam hal ini bisa oleh raja maupun kepala pemerintahan dalam suatu negara.

Pers Libertarian (Libertarianism Media Theory), lebih mengedepankan kebebasan pers dalam tujuannya untuk menyiarkan kebenaran atau realita yang terjadi di tengah masyarakat

Pers Tanggung Jawab Sosial (Social Responsibility Theory), adalah teori yang timbul atas keresahan para penganut teori ini terhadap kebebasan pers yang berlandaskan prinsip pers libertarian. Menurut teori ini, para pers libertarian dirasa terlalu bebas dalam hal yang mereka anggap sebagai 'menyiarkan kebenaran' yang seakan telah melupakan adanya efek langsung yang timbul terhadap masyarakat.

Terakhir adalah Teori Pers Totalitarian (Totalitarian Media Theory), atau yang juga dikenal dengan istilah The Soviet-Communist Theory. Perbedaan yang paling mendasar dari teori pers totalitarian dan otoriter adalah, jika pers otoriter berfungsi penuh untuk mengabdikan diri mereka kepada pemerintahan dalam rangka mendukung pemerintahan yang otoriter, maka pers totalitarian lebih cenderung berkontribusi terhadap keberlanjutan sistem sosialis dengan memberikan pandangan yang objektif tentang masyarakat dan dunia dalam batas-batas prinsip marxisme-leninisme.

Teori Priming dan Framing

Kenneth Newton dan Jan W.Van Deth berpendapat bahwa ada 4 (empat) teori yang bisa digunakan untuk menjelaskan ada atau tidaknya efek yang ditimbulkan oleh media atau 
pers terhadap masyarakat, diantaranya Teori Penguatan, Teori Setting Agenda, Teori Priming dan Framing, serta Teori Efek Langsung.

Penulis lebih menaruh perhatian kepada Teori Priming dan Framing untuk digunakan dalam membantu memahami maksud dan isi daripada penelitian ini. Menurut teori tersebut, media massa dapat mempengaruhi masyarakat agar fokus terhadap isu-isu tertentu yang diangkat media, diatas isu yang lain. Disisi lain, media juga melakukan framing dengan apa yang disebut sebagai set up yang bertujuan untuk mempengaruhi penafsiran pembaca, pemirsa, dan pendengar tentang suatu isu (Marijan, 2010, hal. 282). Ketika media mengangkat suatu isu atau informasi untuk disebarluaskan, akan berdampak signifikan terhadap pikiran masyrakat atau audiencenya. Media memang tidak dapat menentukan pemikiran seseorang, namun media dapat mempengaruhi apa yang akan dipikirkan seseorang.

Teori Sudut Pandang (Standpoint Theory)

Penulis menggunakan Teori Sudut Pandang atau Standpoint Theory yang di pelopori oleh Sandra Harding dan Julia Woods, meski mereka hanyalah satu dari beberapa orang yang mempelopori teori ini (Aderia, 2020).

Menurut mereka, ketika seseorang berbicara dari sisi yang berlawanan dari suatu relasi kuasa, perspektif yang hadir dari orang yang memiliki kekuasaan lebih lemah dapat menghadirkan perspektif yang lebih objektif, daripada orang yang berada di sisi kekuasaan yang kuat. Berdasarkan teori ini pula, Little John dan Foss, menekankan bahwa kondisi dari kehidupan individu mempengaruhi bagaimana individu tersebut memahami dan mengkonstruksi dunia sosial.

Dengan berdasar pada teori tersebut, diharapkan peneliti dapat mengidentifikasi perspektif dari 2 (dua) sisi yaitu dari sisi para jurnalis yang menerima kekerasan maupun dari sisi oknum pihak kepolisian yang melakukan kekerasan.

\section{Kebebasan Pers dalam Kerangka Negara Indonesia}

Negara demokrasi hakikatnya adalah negara dimana sistem pemerintahannya didasarkan pada prinsip-prinsip dasar rule of law, dimana menurut A.V Dicey, setidaknya ada 3 (tiga) unsur rule of law, yaitu supremasi aturan/hukum dan tidak adanya kekuasaan yang sewenang wenang, equality before the law, dan terjaminnya hak rakyat dalam masyarakat (Budiarjo, 2009).

Hak rakyat yang paling dasar pada negara demokrasi adalah kebebasan atau freedom, sebagaimana gagasan John Locke mengenai hak dasar manusia yaitu life, liberty, dan property. Sebenarnya jika ingin melihat lebih jauh, konsep liberty yang diusung oleh Locke, memang berbeda dengan konsep dari freedom atau kebebasan. Namun liberty itu sendiri, merupakan konsep yang berangkat dari kebebasan atau freedom yang sudah melekat pada diri manusia (Heywood, 2004, hal. 254).

Kebebasan yang dimaksud tentunya berbeda-beda dalam setiap negara yang menganut demokrasi, tergantung pada hukum yang ada pada berbagai negara tersebut dalam mengatur makna kebebasan. Kebebasan yang paling umum tergambar dalam negara demokrasi, setidaknya adalah kebebasan berpendapat (freedom of expression) dan kebebasan pers (freedom of the press). (Marijan, 2010, hal. 285) 
Kebebasan pers dalam sebuah negara yang bercorak demokrasi dimaksudkan sebagai penentu demokratis atau tidaknya suatu negara, dikarenakan corak umum negara yang demokratis, biasanya sangat menjunjung tinggi kebebasan berpendapat masyarakatnya. Pers sebagai fasilitator, memegang peranan penting dalam masyarakat karena dianggap mampu mempengaruhi masyarakat dalam suatu negara. Selain karena mereka adalah sarana penghubung komunikasi politik antara pemerintah dengan audiens atau masyarakat, mereka juga dapat berfungsi sebagai watchdog atau agen yang mengontrol kinerja pemerintahan. Asumsi tersebut berdasarkan teori setting agenda menurut Kenneth Newton dan J.W Van Deth yang menurut mereka, memang media atau pers tidak dapat menentukan apa yang dipikirkan masyarakatnya, namun media dapa dan memiliki pengaruh terhadap apa yang dipikirkan masyarakat (Marijan, 2010, hal. 283).

Berdasarkan argumen diatas, tidak mengherankan jika Edmund Burke menyebut pers disebut sebagai pilar ke-4 (empat) dalam negara demokrasi atau bisa disebut the four estate setelah lembaga eksekutif, legislatif, dan yudikatif karena mereka mempunyai kedudukan yang penting dalam negara, khususnya negara demokrasi. Burke mengatakan bahwa pentingnya media atau pers di dalam suatu negara, diantaranya sebagai sumber independen dari pengetahuan, serta bukan hanya menginformasikan kepada masyarakat mengenai politik. namun juga melindungi mereka dari praktik abuse of power atau penyelewengan kekuasaan oleh pejabat pemerintahan (Nair, 2011: 44). Dalam perkembangannya, pers menemui beragam bentuk di berbagai belahan dunia. Jika kita ingin mengetahui macammacam bentuk pers, maka jika merujuk kepada 4 Teori Pers (Four Theories of The Press) yang digagas oleh Fred. S. Siebert, Wilburm Scharm, dan Theodore Peterson pada tahun 1996, kita akan menjumpai 4 bentuk pers yang diantaranya adalah Pers Otoritarian (Authoritarianism Media Theory), Pers Libertarian (Libertarianism Media Theory), Pers Tanggung Jawab Sosial (Social Responsibility Theory), dan Pers Totalitarian (Totalitarian Media Theory).

\section{Pers Otoritarian (Authoritarianism Media Theory)}

Teori yang berkembang pada abad ke-16 di negara-negara monarki Eropa ini, merupakan teori yang dimana segala bentuk komunikasi yang berkaitan dengan penyampaian buah pikiran maupun itu bentuk kritik, gagasan, dan lain sebagainya, difiltrasi oleh penguasa (dalam hal ini bisa raja atau kepala pemerintahan) terlebih dahulu, sehingga hal-hal yang berbau mengancam posisi penguasa serta stabilitas kondisi sosial politik suatu negara, dapat teridentifikasi dengan mudah. Maka dari itu, bentuk komunikasi yang terbangun dalam negara yang menganut Pers Otoriter, adalah komunikasi satu arah, yaitu dari atas kebawah (topdown) yang lebih lumrah disebut sebagai instruksi.

Tujuan awal dari teori pers otoritarian yang dimana menurut Baran \& Davis, adalah untuk memelihara stabilitas sosial dan politik suatu negara. Seiring perkembangannya, negara yang menganut Pers Otoriter seakan menyimpang dari jalurnya dan lebih digunakan ke arah membantu pemerintahan yang otoriter dalam hal melancarkan agitasi dan propaganda yang dibuat pemerintah suatu negara tersebut, untuk masyarakatnya (Triyono, 2013, hal. 195).

Teori ini mempunyai fungsi dan tujuannya yang didasarkan atas pemahaman bahwa, hanya dengan menjadi anggota masyarakat, seseorang dapat mewujudkan potensinya secara 
penuh. Sedangkan jika hanya menjadi individual, akan sulit untuk mencapai tujuan dan kepentingannya karena dihadapkan dengan ruang gerak yang terbatas.

2. Pers Libertarian (Libertarianism Media Theory)

Teori yang berkembang pada akhir abad ke-17 ini, bertumpu pada asumsi para libertarian bahwa sebenarnya adalah kodrat manusia untuk mencari kebenaran demi kehidupan yang lebih baik. Dalam negara yang menganut pers libertarian, mereka lebih cenderung untuk mengawasi jalannya pemerintahan, serta pers bukan lagi semerta-merta sebagai alat pemerintahan yang berfungsi untuk melancarkan agitasi dan propaganda yang dibuat negara untuk masyarakatnya.

Dengan menjadi institusi yang bertujuan untuk menyiarkan kebenaran atau realita atas kondisi yang terjadi di tengah masyarakat tersebut, segala pendapat serta gagasan yang hadir dari berbagai elemen di masyarakat, harus diberikan kesempatan yang sama dalam hal publikasinya. Menurut mereka, hanya dengan seperti itulah kebenaran yang sebenarnya baru akan muncul. Satu hal lain yang juga tidak dapat terlepas dari teori pers libertarian adalah, pers atau media harus dapat lepas dari segala hal yang berbau pengkerdilan atas kebebasan pers dalam menulis ataupun menyiarkan berita yang sesuai dengan tujuannya yaitu, menghadirkan kebenaran.

Dalam Media Democarcy (1991), John Keane setidaknya menuturkan beberapa konsep dasar dari kebebasan pers yang diantaranya adalah sebagai berikut;

a) teologi: menyediakan forum bagi orang untuk menilai benar dan salah,

b) kebebasan individu: kebebasan pers adalah yang terkuat, setidaknya bebas dari elit politik,

c) kebenaran: kebohongan dan kesalahan harus dikonfrontasi, dan gagasan itu harus didiskusikan dan diuji, jika tidak maka itu hanya menjadi dogma (Triyono, 2013, hal. 196).

\section{Pers Tanggung Jawab Sosial (Social Responsibility Theory)}

Teori Pers Tanggung Jawab Sosial biasa disingkat SRT (Social Responsibility Theory) ini muncul karena ketidakpuasan atas sistem pers libertarian yang dinilai terlalu bebas dan seakan melupakan tanggung jawab mereka sebagai institusi yang membantu mencari, memperlihatkan, dan menyebarluaskan makna kebenaran.

Menurut penganut teori ini, media mempunyai dampak yang signifikan atas apa yang dia beritakan dan hal tersebut mempengaruhi masyarakat, dan seakan para penganut pers libertarian melupakah hal tersebut. Akibatnya, para penganut SRT menganggap bahwa kebebasan mutlak yang diterapkan para penganut teori kebebasan pers libertarian adalah sebuah bentuk kemerosotan moral, karena dirasa para libertarian hanya berusaha untuk menghibur, memberikan informasi, dan mencari keuntungan tanpa memiliki rasa tanggung jawab terhadap masyarakatnya.

Sebenarnya pemikiran utama teori ini tidak lain dan tidak bukan adalah untuk mengingatkan kembali betapa pentingnya media bagi masyarakat dalam suatu negara. Mereka berpendapat bahwa, media tidak hanya bebas mengemukakan pendapat dan kebebasan dalam mencari kebenaran, namun dalam menjalankan fungsinya, media harus senantiasa menghimpun masyarakat karena apa yang selalu disampaikan oleh media, memiliki efek dan dampak yang signifikan terhadap masyarakat itu sendiri. 
Maka dengan ini, Komisi Kebebsan Pers atau Comission on Freedom of The Press, merumuskan lima persyaratan pers yang isinya sebagai berikut;

a) persyaratan pertama, melaporkan kejadian sehari-hari dengan benar, lengkap dan etis dalam konteks yang bermakna,

b) persyaratan kedua, penyediaan layanan sebagai wadah pertukaran komentar dan kritik,

c) persyaratan ketiga, yang menampilkan gambaran perwakilan dari kelompok dasar dalam masyarakat;

d) persyaratan keempat, bertanggung jawab untuk menyajikan penjelasan tentang tujuan dan nilai-nilai masyarakat,

e) persyaratan kelima, mengupayakan akses penuh ke acara sehari-hari (Triyono, 2013, hal. 198).

4. Pers Totalitarian (Totalitarian Media Theory)

Pers Totaliter yang juga dikenal sebagai Teori Pers Komunis atau The SovietCommunist Theory, merupakan teori pers yang berkembang pada masa komunis. Teori pers totaliter ini bisa dikatakan berbeda dengan teori pers otoriter. Jika teori pers otoriter lebih digunakan oleh pemerintah sebagai alat untuk menyebarluaskan propaganda dan agitasi yang dalam hal ini, pers mengabdikan dirinya untuk pemerintahan yang otoriter yang sedang berkuasa, teori pers komunis merupakan alat negara sepenuhnya atau dapat diakatakan sebagai bagian integral negara dan tunduk kepada negara secara menyeluruh, termasuk kepada idelogi komunisme. Hal penting yang mendasar dari teori ini juga adalah, media tidak diperkenankan untuk dimilki atau untuk kepentingan pribadi, maka dari itu sifat media pada pers totalitarian adalah kepemilikan bersama (Triyono, 2013, hal. 199-200).

Berkaca dari teori tersebut, jika kita ingin mengkategorikan pers di Indonesia, setidaknya kita harus kembali menilik kebelakang, tepatnya sebelum era reformasi atau pada masa kepemimpinan Soeharto. Soeharto sendiri menyikapi kebebasan pers di Indonesia dengan membuat peraturan tentang pers yang salah satunya termaktub pada UU No. 21 Tahun 1982.

Awalnya Soeharto sendiri menaruh perhatian penuh terhadap kebebasan pers di Indonesia yang dianggap sangat terkekang di era Orde Lama. Maka dengan itu, Soeharto membuat landasan untuk pers di Indonesia yang ia namai sebagai Pers Pancasila, denagn tujuan untuk mengamankan dan membantu pemerintah dalam mengatasi gejolak sisa-sisa pemerintahan Soekarno pada era Orde Lama. Lambat laun, Soeharto kian menaruh perhatian tinggi terhadap media-media yang memang dapat mengancam keberlangsungan rezimnya. Lewat peraturan UU No.21 Tahun 182 Tentang Ketentuan Ketentuan Pokok Pers, memberikan kewenangan pemerintah untuk mengontrol sistem pers atau media di Indonesia (Saptohadi, 2011, hal. 129).

Menurut Anggota Dewan Pers, Nezar Patria, dalam diskusi publik yang berjudul "Dari Bredel Sampai Hoax: Mengenang Masa Kelam Kebebasan Pers Era Soeharto”, banyak sebutan yang berkonotasi negatif untuk menggambarkan situasi dan kondisi di era Orde Baru, dan yang paling mudah menurutnya adalah rezim pengendali pers (Firdausi, 2017) (Firdausi, 2017). Menurut Nezar, kontrol pers oleh Orba dapat dilihat dari berita yang dipublikasikan media. Dia menturkan bahwa, kita mungkin dapat menemukan berita tentang kasus Tanjung Priuk 1984, namun anda tidak akan menemukan berita tentang kasus tersebut yang memuat latar belakang atau aktor-aktor yang kemungkinan terlibat di dalamnmya. 
Peneliti Senior Lembaga Studi Pers dan Pembangunan, Ignatius Haryanto yang menjadi pembicara kedua pada diskusi tersebut, juga menuturkan ada beberapa cara yang digunakan era Orde Baru untuk mengkontrol dan mengkerdilkan kebebasan pers, diantaranya seperti sejumlah wartawan yang mendapat telpon misterius agar tidak memuat berita yang sensitif, mencabut izin penerbitan dan percetakan, menentukan pemimpin redaksi sebuah media, serta yang paling terlihat adalah pembredelan pers.

Dari pernyataan diatas, kita dapat melihat bahwasannya pada era Orde Baru dibawah kepemimpinan Soeharto, pers di Indonesia dikategorikan sebagai pers yang otoriter yang mana kebebasan pers begitu di kontrol dan dikekang kuat oleh rezim yang berkuasa dengan berbagai cara yang dilakukan. Setidaknya hal tersebut berlangsung sampai pada demonstrasi besar-besaran Mei 1998 yang terjadi di berbagai daerah oleh berbagai elemen masyarakat, dengan agenda besar untuk menurunkan Soeharto dari jabatan Presiden Republik Indonesia atau bisa kita sebut sebagai aksi Reformasi.

Berhasilnya aksi Reformasi menurunkan Soeharto dan kroni-kroninya, berimplikasi besar terhadap kebebasan pers di Indonesia salah satunya adalah pembentukan Dewan Pers yang independen. Dewan Pers sendiri sudah terbentuk pada tahun 1968 lewat UU. No. 11 Tahun 1966 yang berfungsi sebagai penasihat pemerintah khususnya Departemen Penerangan, walaupun pada realitanya Menteri Penerangan pada masa itu merangkap menjadi Ketua Dewan Pers (Dewan Pers, 2020) (Dewan Pers, 2020).

Perubahan paling krusial terhadap pers di Indonesia terjadi setahun setelah aksi Reformasi adalah, pergantian peraturan tentang pers dari UU No.21 Tahun 1982 menjadi UU No. 40 Tahun 1999 yang diundangkan pada 23 September 1999, dan ditandatangani oleh Presiden Habibie. Salah satu isi perubahan tersebut setidaknya adalah, membentuk Dewan Pers yang independen, dalam artian, hubungan Dewan Pers dengan pemerintahan pun terputus, yang otomatis terjadi perubahan fungsi pada Dewan Pers itu sendiri. Sedari yang awalnya menjadi penasihat pemerintah, kini Dewan Pers berfungsi menjadi pelindung kemerdekaan pers di Indonesia.

Jika kita melihat UU No. 40 Tahun 1999, maka pers di Indonesia dikategorikan dalam bentuk Pers Tanggung Jawab Sosial atau Social Responsibility Theory. Aumsi tersebut berdasarkan fungsi pers di Indonesia pada UU tersebut yang disebutkan dalam Pasal 3 Ayat 1 yang berbunyi;

"Pers nasional mempunyai fungsi sebagai media informasi, pendidikan, hiburan, dan kontrol sosial”.

Lebih lanjut dimana pers di Indonesia tergambar sebagai Pers Tanggung Jawab Sosial, dapat terlihat pada peran pers di Pasal 6 yang secara garis besar adalah pers harus memenuhi hak masyarakat untuk mengetahui, membela nilai-nilai dasar demokrasi, mendorong supremasi hukum dan hak asasi manusia, menyiarkan informasi yang akurat dan benar, serta memperjuangkan keadilan dan kebenaran.

Meskipun peran utama pers di Indonesia pada pasal diatas merupakan ciri-ciri Pers Tanggung Jawab Sosial, tidak ada yang dapat menjamin bahwasannya pers selalu menjadi institusi yang selalu bertanggung jawab kepada masyarakat, tanpa adanya kepentingan masing-masing yang dimiliki oleh berbagai media di Indonesia. Setidaknya dengan ini kita dapat mengetahui bagaimana pers di Indonesia berjalan dengan semestinya yang harus sesuai dengan UU No. 40 Tahun 1999 Tentang Pers. Bentuk pers Indonesia yang sesuai 
dengan Social Responsibility Theory, menyiratkan bahwa pers atau media harus berkontribusi terhadap penjaminan masyarakat memperoleh maupun menyebar informasi. Kebebasan tersebut tidak dapat dikekang, dan dibatasi, sejauh masih berada dalam koridorkoridor hukum yang berlaku, dan tidak menyebarkan informasi yang bersifat bohong atau palsu. Pers yang bercorak SRT, juga senantiasa mengedukasi masyarakat lewat informasi yang mereka berikan, bukan hanya sekedar memberikan hiburan semata, serta meraup keuntungan lewat periklanan, dan sebagai macamnya. Namun, bagaimana jika dalam proses menghimpun berita di lapangan, jurnalis yang menjadi ujung tombak dari pers dan media ini menemukan berbagai hambatan-hambatannya seperti kriminalisasi, intimidasi, pengrusakan dan sebagai macamnya oleh berbagai oknum salah satunya oknum anggota kepolisian?

\section{Aksi Demonstrasi sebagai Arena Pelayangan Kekerasan Terhadap Jurnalis}

Seperti yang telah dijelaskan diawal bahwasannya setidaknya ada unsur kebebasan yang umum tergambar dalam kerangka negara demokrasi, diantaranya adalah kebebasan pers (freedom of the press) dan kebebasan berpendapat (freedom of expressions). John Stuart Mill, seorang filsuf inggris di abad-17 yang pemikirannya sangat berpengaruh terhadap konsep kebebasan juga berependapat bahwa, semakin luas kebebasan berpendapat dibuka dalam sebuah masyarakat atau peradaban, maka masyarakat tersebut akan semakin maju dan berkembang (Sabela \& Pirtaningras, 2017, hal. 81).

Aksi demonstrasi, merupakan sebuah proyeksi daripada kebebasan berpendapat yang berarti bebas untuk mengeluarkan gagasan dan pemikiran, biasanya terjadi di muka umum dan sifatnya kelompok. Aksi demonstrasi sendiri dapat berarti banyak hal, dan yang paling umum biasanya tergambar sebagai reaksi atas ketidakpuasaan sebagian masyarakat terhadap kinerja atau kebijakan yang dikeluarkan pemerintah dalam suatu negara. Yang perlu diketahui adalah, demonstrasi di setiap negara yang menganut demokrasi, pasti diatur serta dijamin dalam hukum di setiap negara tersebut. Di Indonesia sendiri, hukum yang mengatur tentang aksi demonstrasi, termaktub dalam Pasal 6, Undang-Undang No. 9 Tahun 1998, yang secara garis besar para aksi demonstrasi harus melakukan penghormatan terhadap hak serta kebebasan orang lain, menjaga dan menghormati keamanan dan ketertiban publik, serta mematuhi hukum dan peraturan yang berlaku. Tentu saja sebagian masyarakat tersebut melakukan aksi demonstrasi bukan tanpa alasan, dan mereka pikir hal tersebut bersinggungan dengan kepentingan banyak pihak dari berbagai elemen masyarakat, atau bisa bersifat ancaman untuk beberapa kelompok di masyarakat tersebut. Dalam hal ini, media atau pers, sungguh memegang peranan yang sangat besar terhadap penyebarluasan informasi yang diterima masyarakat, karena pers atau media tersebut, secara tidak langsung menjadi katalisator terjadinya aksi demonstrasi.

Untuk melihat kondisi tersebut, Katrin Voltmer (Marijan, 2010, hal. 286-287), menawarkan dua sudut pandang untuk melihat posisi media atau pers dalam sistem politik di sebuah negara. Yang pertama, dia menyebut media atau pers sebagai 'marketplace of ideas', dimana media merupakan tempat untuk mengemukakan pendapat dan arena untuk debat publik. Menurutnya, melalui debat publik tanpa intervensi negara yang dihadirkan oleh media, akan semakin memungkinkan kebenaran untuk muncul di tengah masyarakat. Kedua, dia menyebut media sebagai aktor yang terlibat langsung dalam proses komunikasi politik itu sendiri. Menurutnya, media atau pers tidak dapat lagi dilihat hanya sebagai sarana 
atau medium komunikasi politik antara aktor politik dengan audience atau masyarakat semata, namun mereka juga dapat dilihat sebagai aktor yang terlibat langsung dalam proses komunikasi politik tersebut.

Sebagai aktor yang ikut terlibat, media atau pers, dapat sangat berpengaruh baik terhadap aktor politik maupun kepada massa atau audience itu sendiri. Dalam pandangan ini kita dapat menyimpulkan bahwa, media sebagai aktor juga mempunyai kepentingan mereka masing-masing yang memungkinkan mereka masuk lebih jauh kepada pemihakanpemihakan. Jika kita menggunakan sudut pandang Voltmer yang pertama dimana media sebagai 'marketplace of ideas', memang pers adalah medium yang cocok untuk para demonstran melandaskan gerakannya. Informasi yang diberikan oleh media yang kredibel, dapat menjadi acuan demonstran untuk dirujuk menjadi kajian dan menjadi substansi yang akan dikemukakan mererka di muka umum. Meski begitu, informasi yang dihadirkan oleh pers atau media, bukan semata-mata hal yang mudah. Jurnalis atau wartawan yang meliput berita, kerap menjadi incaran sebagian oknum dari berbagai elemen di masyarakat. Mereka sebagai 'taring' pers, kerap menjumpai perlakuan kekerasan yang diantaranya seperti intimidasi langsung, penghalangan liputan, pengrusakan alat dan hasil liputan, bahkan sampai dengan kekerasan fisik.

Namun, kebebasan dalam berekspresi seperti halnya demonstrasi, serta kebebasan pers, menemui paradoksalnya tersendiri ketika dihadapkan dengan realita di lapangan. Ketika pertemuan tensi terjadi antara elemen masyarakat yang berdemonstrasi dengan anggota kepolisian sebagai pengaman di sejumlah titik demonstrasi, maka yang terjadi adalah bentrokan yang tidak terelekan antara kedua pihak tersebut. Didalam kondisi tersebut, media atau pers harus tetap profesional dalam menjalankan tugasnya menghimpun berita. Diantara bentrokan yang terjadi, sang jurnalis harus senantiasa meliput semua kejadian yang terjadi di lapangan, termasuk saat oknum anggota kepolisian terliput saat sedang bentrok dengan para demonstran. Inilah yang kerap menjadi benang merah, mengapa jurnalis kerap mendapatkan perlakuan kekerasan oleh oknum anggota kepolisian saat meliput berita, khususnya saat meliput aksi demonstrasi. Hal tersebut dapat kita lihat dalam laporan Aliansi Jurnalis Indonesia dalam laman webnya.

Berkaca dari hal tersebut, aksi demonstrasi yang umum terjadi di tengah masyarakat, biasanya merupakan respons atau reaksi dari sebagian masyarakat terhadap lembaga atau institusi pemerintah maupun non pemerintah, atas kinerja maupun kebijakan publik yang dikeluarkan oleh lembaga atau institusi tersebut.

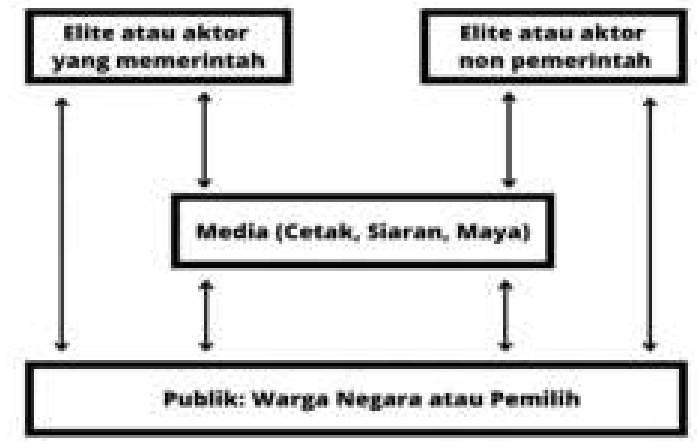

Gambar 1. Alur Komunikasi Politik Modern (Marijan, 2010, hal. 286) 
Merujuk pada alur komunikasi politik modern diatas, peranan media sangat berpengaruh terhadap aktor politik maupun massa dalam komunikasi politik. Menurut Kacung Marijan, yang paling memainkan peran dalam komunikasi politik di suatu negara adalah para elit yang duduk di pemerintahan atau governing elite, dan yang paling pasif adalah publik.

Disisi lain, ada aktor-aktor lain yang menurutnya juga ikut andil dan punya pengaruh besar dalam komunikasi politik tersebut, yaitu elit non pemerintah atau non governing elite, dan media atau pers itu sendiri. Selain elit pemerintah maupun non pemerintah dapat membangun komunkasi politik secara langsung dengan warga negara atau publik, warga negara juga menggunakan media untuk memperoleh informasi ataupun mengemukakan kepentingan dan aspirasi mereka. (Marijan, 2010, hal. 286).

Sepanjang Tahun 2019, setidaknya terdapat 2 demonstrasi besar akibat gejolak perpolitikan yang terjadi di dalam negeri, diantaranya aksi demonstrasi yang terjadi di depan gedung Badan Pengawas Pemilu (Bawaslu) pada bulan Mei yang dipicu akibat ketidakpercayaan pendukung Prabowo-Sandi dalam perhitungan suara pada Pemilu Presiden 2019, serta aksi demonstrasi oleh mahasiswa dan mahasiswi untuk menolak Rancangan Kitab UndangUndang Hukum Pidana (RKUHP) oleh DPR RI pada bulan September yang bisa disebut sebagai aksi 'Reformasi Dikorupsi'. Dalam laman Advokasi AJI yang menampilkan data kekerasan yang dialami jurnalis saat meliput kedua aksi demonstrasi tersebut, sepanjang tahun 2019 terhitung sejak bulan Januari sampai dengan Desember tahun 2019 di Jakarta sampai dengan 2020, terdapat setidaknya 15 kasus 83 kasus kekerasan yang dialami jurnalis, dan 1034 diantaranya dilakukan oleh oknum anggotapihak kepolisian. serta 12 dari 34 kasus tersebut, terjadi saat jurnalis sedang meliput aksi demonstrasi yang terjadi di Jakarta. Bentuk kekerasan yang ditemui jurnalis pun beragam, mulai dari kekerasan fisik, intimidasi lisan, serta pengrusakan alat dan/atau hasil liputan.

Tabel 1. Kekerasan Yang Dialami Jurnalis Oleh Oknum Anggota Kepolisian Saat Meliput Aksi Demonstrasi di Jakarta Tahun 2019

\begin{tabular}{|l|l|}
\hline Bentuk Kekerasan & Jumlah Kasus \\
\hline Kekerasan Fisik & 6 Kasus \\
\hline Intimidasi Lisan & 1 Kasus \\
\hline $\begin{array}{l}\text { Pengrusakan Alat dan } \\
\text { Hasil Liputan }\end{array}$ & 3 Kasus \\
\hline Total Kasus & 10 Kasus \\
\hline
\end{tabular}

Source: Diolah oleh Penulis dari Laman Advokasi AJI 
Data yang penulis sajikan diatas merupakan hasil analisis penulis dari laman Advokasi AJI yang penulis olah kedalam bentuk tabulasi. Data-data yang dikategorikan dalam bentuk kekerasan tersebut sebelumnya telah dikategorikan dalam laman tersebut, dimana dalam setiap kasus telah dituliskan kategori bentuk kekerasannya, sehingga penulis hanya mengikuti hasil laporan yang diunggah oleh AJI di laman webnya. Namun, ketika penulis menganalisis lebih dalam mengenai pengakuan korban jurnalis yang mengalami tindak kekerasan oleh oknum anggota kepolisian dalam laporan di laman Web AJI tersebut, dalam satu kasus tidak jarang ditemukan pengakuan korban yang dapat merepresentasikan 2 atau 3 bentuk kekerasan sekaligus. Beberapa contoh diantaranya seperti bentuk laporan pengakuan dari Ryan Suhendra jurnalis dari CNN Indonesia.com yang mendapatkan tindak kekerasan dari oknum anggota brimob saat sedang meliput aksi demonstrasi Pendukung Prabowo-Sandi pada bulan Mei silam. Dalam laporan tersebut, beliau mengatakan bahwa dirinya bergabung dengan barisan masa aksi di sekitaran Tanah Abang Jakarta Pusat pada 22 Mei 2019 dan dirinya meliput massa aksi sedang melempar batu kearah barisan anggota kepolisian yang berjaga. Namun pada pukul 09.30 WIB, kondisi sudah chaos dan beliau meliput polisi sedang menangkap provokator. Tidak sampai satu menit, beliau mengakui bahwa ada seorang anggota brimob yang tidak dikenal namanya memaksa dirinya menghapus video hasil liputan, serta dirinya mendapatkan pukulan dibagian leher, bahu, dan wajah. Beliau menambahkan bahwa oknum anggota brimob tersebut mengatakan "Giliran begini lu liput, massa aksi yang serang kita, malah enggak".

Laporan serupa juga datang dari Budi Tanjung, jurnalis CNN TV, yang meliput aksi serupa namun berbeda waktu dan tempat. Beliau meliput di sekitaran gedung Bawaslu pukul 02.00 WIB malam hari. Karena beliau merasa haus, dirinya melenggang ke warung depan Gereja Kristen Indonesia (GKI) sekiataran M.H Thamrin, dan beliau mendapati seorang pendemo ditangkap oleh dan dibawa oleh anggota brimob ke arah gedung Bawaslu, sontak Budi merekam kejadian tersebut dengan handphone miliknya. 5 menit kemudian dirinya merekam kejadian seorang pendemo digelandang aparat di depan GKI yang sangat dekat dengan posisi dia sedang beristirahat minum. 4-5 oknum anggota brimob tersebut menendang pendemo tersebut yang sudah diam tak berdaya. Beberapa menit setelahnya, dia didatangi 4-6 oknum anggota brimob dan menarik paksa handphonenya serta menyuruhnya untuk menghapus video tersebut. Karena bersikeras berkata bahwa dirinya adalah jurnalis, dan itu sudah hak beliau untuk merekam, Budi pada bagian kepala belakang dan samping telinganya. Salah satu brimob senior mengatakan pada Budi “ kamu jangan rekam sembarangan”.

Berdasarkan laporan data kekerasan yang diunggah AJI dalam laman Advokasi AJI dengan kurun waktu Januari 2019-2020, dari 34 kasus, hanya ditemukan 12 kasus kekerasan yang dialami jurnalis oleh pihak kepolisian, selama meliput aksi demonstrasi yang terjadi di Jakarta. 12 kasus tersebut terjadi saat jurnalis sedang meliput aksi demonstrasi kericuhan pasca pemilu 2019 yang terjadi di depan gedung Bawaslu pada bulan Mei 2019, dan aksi demonstrasi Reformasi Dikorupsi yang terjadi di depan gedung DPR/MPR RI pada 24-30 September 2019.

Adapun salah satu laporan kronologi pada September 2019 dari data dalam laman AJI tersebut yang korbannya kebetulan penulis kenal karena beliau satu Universitas dengan penulis, yakni Haris Prabowo, Jurnalis dari Tirto.id. Beliau yang mengalami tindak kekerasan oleh oknum anggota kepolisian saat meliput aksi demonstrasi Reformasi 
Dikorupsi dari data dalam laman AJI tersebut yang, juga dimuat dalam artikel di laman media Tirto.id yang ditulis oleh Ade Briantika dengan judul "Parade Kekerasan Polisi terhadap Wartawan Sepanjang 2019”. Ade menuturkan bahwa salah satu teman penulis yang juga sebagai jurnalis bernama Haris Prabowo, diringkus oleh salah satu anggota kepolisian ketika dia merekam adu argumentasi antara anggota kepolisian dengan anggota marinir di area RS Gigi dan Mulut, Ladokgi TNI AL RE Martadinata pada 30 September 2019. Polisi tersebut menyeret Haris dan bertanya apakah Haris ikut melakukan aksi lempar batu atau tidak. Pertanyaan menyudutkan tersebut dibantah Haris dengan berkata bahwa diapun datang dari arah pihak polisi. Tak percaya dengan perkataan Haris, seorang anggota polisi menggeledah Haris dan menemukan selongsong gas air mata, yang diakui Haris sebagai keperluan reportase. Selanjutnya tanpa alasan yang jelas, kepala Haris dipiting dan ia diseret berjalan cepat menuju gedung parlemen.

Melihat data kekerasan terhadap jurnalis oleh oknum anggota kepolisian dalam laporan AJI tersebut, beberapa kasus terlihat bahwa persis yang penulis katakan sebelumnya bahwa benang merah mengapa jurnalis kerap mendapatkan perlakuan kekerasan dari oknum kepolisian yakni mereka tidak terima jika jurnalis meliput tindakan kekerasan mereka kepada masa aksi demonstrasi. Hal tersebut seakan menyiratkan perlakuan tidak adil yang dilakukan jurnalis, karena yang tampak ke permukaan berita hanya tindakan kekerasaan yang dilakukan oknum anggota kepolisian. Hal lain yang menurut penulis juga dapat menjadi kemungkinan adalah para oknum yang melakukan tindakan sewenang-wenang tersebut takut terkena pendisiplinan jika mereka terkekspos di dalam berita. Maka dari itu, tidak segan para oknum anggota kepolisian terus menerus memaksa para jurnalis untuk menghapus hasil rekaman jika jurnalis meliput tindakan kekerasan oknum anggota kepolisian. Hal ini juga selaras dengan hasil analisis penulis terhadap 10 kasus laporan pengakuan korban tindakan kekerasan oknum anggota kepolisian terhadap jurnalis saat sedang meliput kedua aksi besar di Jakarta pada 2019 silam pada laman AJI tersebut dimana, 8 dari 10 hasil pengakuan korban dalam laporan tersebut, berisi ketidakterimaan oknum anggota kepolisian terhadap hasil liputan jurnalis, memaksa mereka menghapus hasil liputan, dan tidak jarang berujung kepada pelayangan tindakan kekerasan. Menanggapi hal tersebut, artikel dalam laman Tempo, memuat pernyataan tajam nan sinis dari AJI yang menegaskan bahwa polisi adalah musuh kebebasan pers, dimana Abdul Manan, Ketua Umum AJI menuding polisi secara sengaja melakukan pembungkaman dan kekerasan terhadap jurnalis sepanjang tahun 2019 (Tempo, 2019).

Disisi lain, Direktur Eksekutif LBH Pers, Ade Wahyudin, menjelaskan bahwa sepanjang tahun 2019, terdapat 75 kasus kekerasan terhadap jurnalis, 2 kasus terhadap pers mahasiswa, dan 2 perkara menimpa narasumber, dengan pihak yang paling tinggi melayangkan kekerasan adalah pihak kepolisian sebanyak 33 kasus, disusul di posisi kedua oleh masyarakat sebanyak 17 kasus, dan pelaku lain seperti pejabat publik dengan 7 kasus serta pengusaha sebanyak 6 kasus (Wardah, 2020).

Ditahun 2020, data yang digunakan penulis tentang tindak kekerasan yang dialami jurnalis oleh oknum anggota kepolisian, yakni LBH Pers juga menerbitkan Annual Report LBH Pers Tahun 2020 yang diberi judul "Demokrasi Tenggelam Pers Dibungkam: Kebebasan Pers di Tengah Pandemi” yang berisikan laporan kekerasan terhadap jurnalis 
sepanjang tahun 2020, mulai dari kriminalisasi, pembungkaman pers, hingga kebebasan berekspresi.

Dalam laporan tersebut, dijelaskan bahwa sejak 1 Januari sampai 10 Desember 2020, terdapat 117 kasus kekerasan terhadap jurnalis yang menurutnya naik secara signifikan sebesar 32\%, dibandingkan dengan tahun 2019 yaitu sebanyak 79 kasus.

\section{LATARBELAKANG PELAKU}

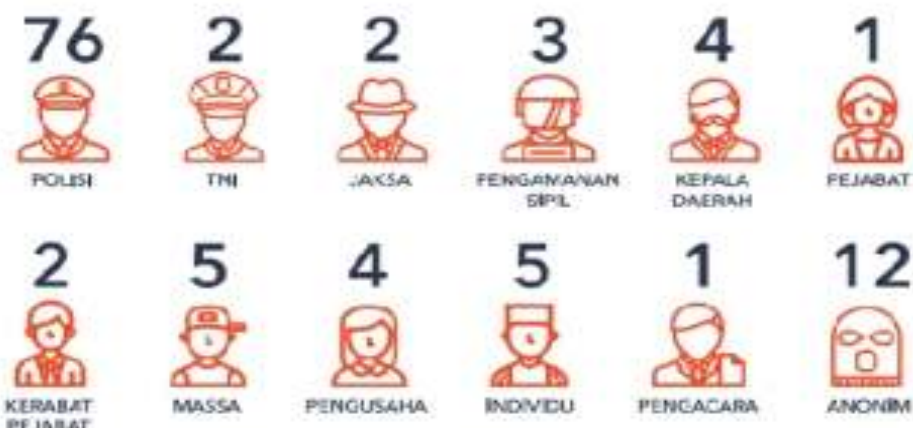

Gambar 2. Latar Belakang Pelaku Kekerasan Terhadap Jurnalis Source: Annual Report LBHPers 2020

Bentuk kekerasan yang dialami jurnalis pada tahun 2020 tersebut, juga lebih beragam. Bukan hanya pada kekerasan fisik, pengrusakan alat atau hasil liputan, dan intimidasi lisan semata. Lebih jauh daripada itu, jurnalis juga kerap menerima bentuk kekerasan lain seperti serangan digital, penangkapan kerja, bahkan kriminalisasi.

\section{BENTUK KEKERASAN}

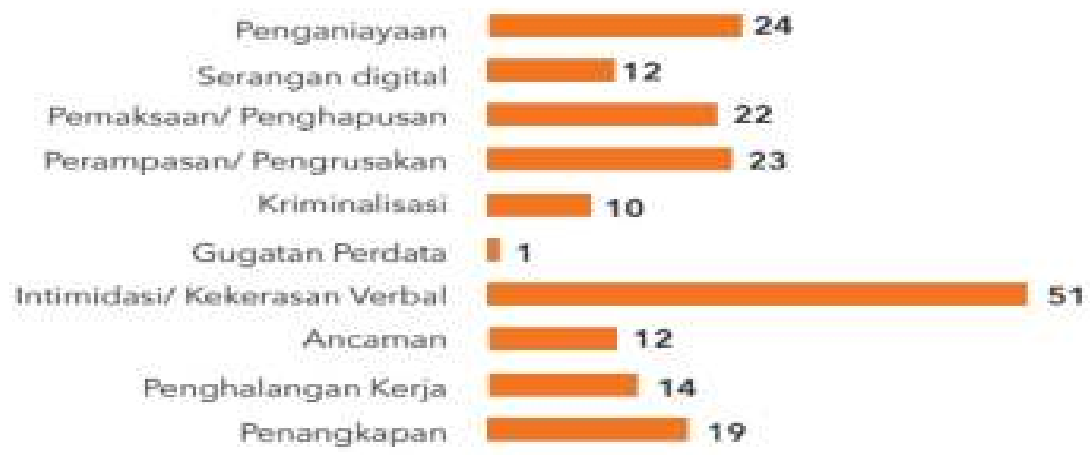

Gambar 2. Bentuk Kekerasan yang Dialami Jurnalis Selama 2020

Source: Annual Report LBHPers 2020 


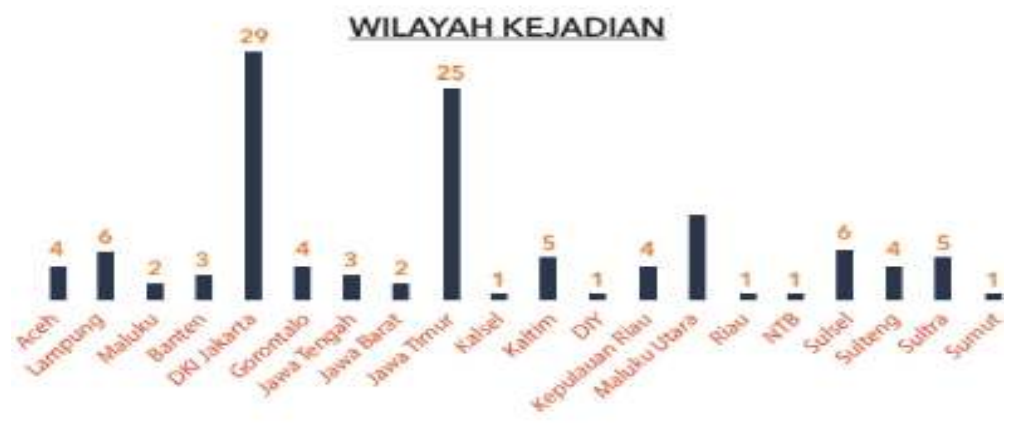

Gambar 3. Wilayah Kejadian 117 Kekerasan Selama 2020 Source: Annual Report LBHPers Tahun 2020

Dari Total 117 kasus tersebut, menunjukan bahwa kepolisian masih menduduki posisi pertama sebagai pihak yang paling sering melayangkan kekerasan terhadap jurnalis dengan total mencapai 76 kasus, dengan 71 kasus diantaranya terjadi saat jurnalis sedang meliput aksi demonstrasi atas pengesahan Omnibus Law pada Oktober 2020 kemarin. Sebaran wilayahnya pun bukan hanya terjadi di satu daerah, namun terjadi juga di daerahdaerah lain di Indonesia, mengingat aksi Reformasi Dikorupsi dan Aksi Tolak RUU Ciptaker Omnibus Law merupakan aksi nasional. Berdasarkan data diatas, DKI Jakarta merupakan daerah tertinggi dimana kekerasan terhadap jurnalis paling sering dilayangkan dengan total 29 kasus, dilanjut oleh Jawa Timur di posisi kedua dengan 25 kasus.

Berdasarkan data yang disuguhkan AJI dan LBH Pers, kita bisa melihat bahwa posisi pertama yang melayangkan kekerasan terhadap jurnalis, dimenangkan oleh pihak kepolisian. Dalam setiap aksi demonstrasi, kepolisian sebagai aparat penegak hukum, sebenarnya wajib melakukan pengamanan terhadap penyampaian pendapat di muka umum, agar dapat berjalan dengan baik dan tertib. Peraturan lebih lanjut mengenai pengamanan oleh pihak kepolisian terhadap jalannya aksi demonstrasi, termaktub dalam Pasal 13 Peraturan Kepala Kepolisian Negara Republik Indonesia Nomor 9 Tahun 2008 (Pasal 13 Perkapolri 9/2008) yang secara garis besar, pihak kepolisian harus menghormati hak asasi manusia, asas legalitas, dan prinsip praduga tak bersalah, serta melakukan pengamanan. Memang dalam setiap aksi demonstrasi, kita tidak dapat menjamin kegiatan tersebut dapat terlaksana dengan baik dan tertib, memang dalam setiap aksi terdapat oknum-oknum tidak bertanggung jawab, yang berusaha untuk memprovokasi sehingga jalannya aksi berubah yang sedari damai, menjadi kericuhan. Ketika terjadi kericuhan, masing-masing pihak akan otomatis untuk menyelematkan dan mengamnkan diri masing-masing. Asumsi tersebut, berdasarkan pernyataan dari Kadiv Humas Polri, Irjen Argo Yuwono, yang berkata bahwa selain kepolisian mengamankan jalannya aksi, mereka juga melindungi jurnalis. Namun ketika keadaan sudah mulai chaos, anggota pun fokus untuk melindungi dirinya. (CNN Indonesia, 2020)(CNN Indonesia, 2020).

Jika kita merujuk pada hasil penelitian terdahulu, yakni karya "Implementasi Perlindungan Hukum Bagi Wartawan Korban Kekerasan Yang Dilakukan Oleh Kepolisian”, karya Hariardo Haloho dan Arie Steven pada 2016 silam, memang jelas dalam UU No. 2 Tahun 2002 tentang Kepolisian Negara Republik Indonesia dimana anggota kepolisian 
mempunyai wewenang diskresi jika dihadapkan dengan kondisi mendesak. Namun, jika kita melihat hasil data tindak kekerasan yang dialami jurnalis diatas, wewenang diskresi seakan menjadi legal standing para oknum kepolisian untuk bersikap sewenang-wenang saat aksi demonstrasi, khususunya terhadap masa aksi dan jurnalis. Memang tidak kita tidak dapat menyalahkan pihak kepolisian semata, yang melakukan hal tersebut hanyalah oknum dari anggota kepolisian, dan kita senantiasa tidak boleh terjebak kedalam overgeneralization. Alih-alih menjadikan diskresi menjadi penyebab utama sebagai tindak kekerasan oknum anggota kepolisian terhadap jurnalis, penulis juga mempunyai pandangan lain mengenai fenomena ini.

Dengan menggunakan teori dari Kenneth Newton dan J.W Van Deth yakni Teori Priming dan Framing (Marijan, 2010, hal. 282-283). Menurut mereka, media massa dapat mempengaruhi masyarakat agar fokus terhadap suatu isu yang dihadirkan, diatas isu yang lain. Disisi lain, media juga melakukan framing dengan apa yang disebut sebagai set up yang bertujuan untuk mempengaruhi penafsiran pembaca, pemirsa, dan pendengar tentang suatu isu. Maka jika kita korelasikan terhadap isu tentang kekerasan yang kerap dialami oleh jurnalis terhadap oknum pihak kepolisian, tergambar bahwa memang media mencoba untuk melakukan framing terhadap massa dengan membuat berita tentang berbagai kekerasan yang dialami wartawan saat meliput aksi demonstrasi yang dilakukan oleh pihak kepolisian. Disisi lain, sangat memungkinkan mereka untuk juga melakukan priming, yang mana sangat mempunyai andil yang besar dalam mempengaruhi penafsiran para pembaca berita mereka.Memang media tidak dapat menentukan apa yang akan dipikirkan oleh audiencenya, namun mereka dapat mempengaruhi apa yang akan dipikirkan oleh audience-nya. Bukan tidak mungkin jika memang ketakutan oknum anggota kepolisian dilandaskan atas hal ini, karena jika sampai pers atau media terus menerus mengekspos tindak kekerasan yang dilakukan oknum anggota kepolisian, maka imbasnya akan luas dan berkepanjangan, yakni menurunnya citra Polri dimata masyarakat. Sosok yang direpresentasikan sebagai pengayom masyarakat, dapat luntur seketika ketika pembaca terus menerus disuguhkan dengan tindak kebrutalan polisi saat mengamankan aksi demonstrasi. Hal ini selaras dengan pernyataan Bambang Rukminto dari Institute for Strategic Studies (ISESS) yang menyebutkan bahwa arogansi polisi berdampak kepada hilangnya kepercayaan masyarakat yang bisa berujung pada ketidaktaatan hukum (Halim, 2019).

Menurut penulis, fenomena kekerasan oknum anggota kepolisian yang tidak sengaja terekspos oleh jurnalis ini, menjadi denominator masyarakat melakukan perlawanan dan semakin membenci kepolisian. Hal ini menurut penulis juga dapat disebabkan oleh pengalaman tidak menyenangkan yang diterima berbagai elemen masyarakat oleh oknum anggota polisi lain yang seakan menjadi bom waktu dan tinggal menunggu untuk meledak, hanya butuh denominator untuk meledak. Tidak heran jika kata All Cops Are Bastard (ACAB), melalang buana di tembok-tembok lokasi aksi demonstrasi.

\section{Memandang Kebebasan Pers di Indonesia.}

Penulis ingin mencoba menyajikan argumentasi reflektif dengan menggunakan Standpoint Theory dari Sandra Harding dan Julia Woods untuk senantiasa melihat dua sisi mata koin. Standpoint theory, berfokus pada argument dasar bahwa keadaan dari seseoranglah yang menentukan bagimana mereka mengerti dan mengkonstruksikan dunia 
sosial (Aderia, 2020: 73). Segala formulasi dari teori ini berpendapat bahwa sudut pandang muncul ketika seseorang mengenali dan menantang nilai-nilai budaya dan hubungan kekuasaan yang berkontribusi pada subordinasi atau penindasan terhadap kelompokkelompok tertentu. Dengan begitu, kita mendapatkan pandangan alternatif baru bahwa oknum kepolisian tersebut melihat para demonstranlah yang kerap menimbulkan kegaduhan dan kericuhan saat aksi demonstrasi.

Penulis juga tidak akan menyangkal, karena dalam beberapa kali penulis mengikuti aksi demonstrasi seperti aksi RUU KPK, RKHUP, hingga Omnibus Law, ada saja masa aksi yang merusak fasilitas umum, seperti yang terjadi pada 8 Oktober 2020 silam, dimana halte Sarinah dibakar oleh beberapa oknum masa aksi yang tidak bertanggung jawab. Dengan begitu, polisi yang sudah mendapatkan tanggung jawab untuk mengamankan kondisi lapangan saat demonstrasi pun dihadapkan dengan kondisi dilematis jika memang keadaan dilapangan sudah chaos dan mulai ricuh akibat provokator, dan ketika beberapa oknum kepolisian mencoba membela diri dan tidak sengaja ada beberapa dari oknum yang melakukan perlawanan balik ke masa aksi, diliput oleh jurnalis dan terus menerus jadi bahan konsumsi publik sehingga citra Polri menurun, maka dari itu pula oknum kepolisian memandang jurnalis kerap menjadi perhatian tersendiri bagi oknum anggota kepolisian. Audience yang mengkonsumsi berita kebrutalan terhadap masa aksi oleh oknum anggota kepolisian menjadi geram, dan menganggap semua polisi sama, dan inilah yang penulis tekankan diatas bahwa media atau pers menjadi denominator meledaknya bom waktu yang dimiliki oleh sebagian elemen masyarakat, padahal tidak semua anggota kepolisian melakukan hal tersebut, beberapa dari mereka ada pula yang menjalankan tugas pengamanan dengan baik tanpa menggunakan kekerasan. Adapula berbagai pemicu lain yang disebabkan oleh media atau pers, yang mMenurut Wakil Ketua Dewan Pers, Hendry Ch. Bangun, selama 2019, terdapat lebih dari 400-an pengaduan dugaan pelanggaran kode etik jurnalistik kepada Dewan Pers. Diantara banyaknya pengaduan tersebut, kesalahan atau pelanggaran yang sering terjadi adalah, pemberitaan tidak berimbang, tidak akurat, dan menghakimi atau menyimpulkan tanpa disertai data. Henry menambahkan, hal-hal semcam tersebut dapat terjadi dikarenakan kecenderungan pers dewasa ini adalah mendahulukan kecepatan berita, sehingga berita yang ditampilkan terkadang keakuratannya dapat dipertanyakan. (Mardatillah, 2019)(Mardatillah, 2019),

Disisi yang lain kita telah menghabiskan banyak pembicaraan diatas bagaimana jurnalis kerap memandang sinis kepolisian dan nampaknya penulis tidak perlu lagi untuk mengulas lebih banyak sudut pandang dari jurnalis serta pers atau media., Ketua Aliansi Jurnalis Independen, Abdul Manan, turut menyatakan bahwa pihak kepolisian melakukan tindak kekerasan terhadap jurnalis atau wartawan yang sedang meliput aksi demonstrasi, bertujuan untuk menghilangkan bukti. Argumen Manan ini didasarkan pada adanya pola teratur dalam setiap tindak kekerasan yang dilayangkan polisi terhadap jurnalis, yaitu saat jurnalis sedang merekam polisi melakukan tindak kekerasan fisik kepada massa aksi. (CNN Indonesia, 2020)(CNN Indonesia, 2020). Berangkat dari semua pembahasan diatas, perlu kita ketahui bersama bahwa kebebasan pers di Indonesia sendiri memang sudah diatur dalam kerangka hukum yang jelas, serta pelenggaraan pengamanan oleh pihak kepolisian juga sudah termaktub dalam Perkapolri 9/2008. Namun disisi lain, perlu untuk kita merefleksikan kembali mengenai kebebasan pers di Indonesia, dimana para jurnalis yang menjadi sosok 
penting dalam media atau pers, kerap menjumpai segudang perlakuan tidak menyenangkan dari berbagai elemen di masyarakat salah satunya dari oknum dari pihak kepolisian.

Terlepas dari berbagai macam bentuk kekerasan tersebut, memang kekerasan terhadap massa demonstran yang mana jurnalis termasuk didalamnya, pihak kepolisian tidak diperkenankan untuk melakukan hal tersebut. Hal ini ditegaskan oleh Komandan Korps Brimob Polri, Brigjen Abdul Rakhman Basro, dengan berkata bahwa dia senantiasa menginstruksikan kepada jajarannya agar tidak melakukan tindak kekerasan terhadap wartawan. Lebih lanjut dia menegaskan bahwa, instruksi tersebut bukan merupakan komitmen yang berasal darinya, melainkan dari Kapolri langsung. Siapapun anggota yang terbukti melakukan tindak kekerasan terhadap massa aksi, akan ditindaklanjuti dalam bentuk disiplin, kode etik, bahkan pidana. (Briantika, 2019), Namun dengan begini, setidaknya kita mempunyai pandangan alternatif atas fenomena yang penulis angkat.

Sehubungan dengan hal tersebut, memang ada beberapa kesalahan fatal yang kerap dilakukan jurnalis dan melanggar kode etik jurnalis, walaupun telah diatur dalam UU Pers No 4 Tahun 1999 Tentang Pers, dan lebih rinci tentang kode etik jurnalistik yang diatur dalam Peraturan Dewan Pers No.6 Tahun 2008.

Berdasarkan hal tersebut, setidaknya kita juga harus melihat perspektif yang hadir dari sisi pihak kepolisian juga. Karena menurut Harding dan Woods, ketika seseorang berbicara dari sisi yang berlawanan dari suatu relasi kuasa, perspektif yang hadir dari orang yang memiliki kekuasaan lebih lemah dapat menghadirkan perspektif yang lebih objektif, daripada orang yang berada di sisi kekuasaan yang kuat. (Aderia, 2020)

Disisi lain, polisi menanggapi fenomena tersebut dengan menyatakan jaminan untuk menindak lanjuti oknum yang terbukti melakukan tindakan kekerasan tersebut melalui tindakan pendisiplinan, kode etik, maupun pidana, karena hal tersebut bertentangan dengan instruksi Kapolri pada Perkapolri No. 9 Tahun 2008. Hal tersebut tergambar pada pernyataan LBH Pers Makassar yang merupakan tim kuasa hukum dari tiga jurnalis yang menerima tindak kekerasan saat meliput demonstrasi Reformasi Dikorupsi pada 24 September di Makassar. Menurutnya, ini merupakan satu langkah positif dari Kepolisian Daerah Sulawesi Tengah, karena sudah mengeluarkan Surat Pemberitahuan Dimulainya Penyidikan (SPDP), terhadap 3 oknum kepolisian yang melakukan tindakan kekerasan terhadap 3 jurnalis tersebut. (Nurmansyah, 2019)

Dari 2 perspektif diatas, sekali lagi memang sulit pada kenyataanya untuk kita mencoba mengkonstruksikan realita. Sesuai dengan perkataan menurut Little John dan Foss, bahwa kondisi dari kehidupan individu mempengaruhi bagaimana individu tersebut memahami dan mengkonstruksi dunia sosial. (Aderia, 2020)

\section{Kesimpulan}

Akhir dari pembahasan ini akhirnya sampai juga kepada kesimpulan, dimana penulis menyimpulkan bahwa memang bentuk media atau pers di Indonesia adalah bentuk Social Responsibility Theory, dimana media atau pers diharuskan untuk memberikan informasi yang aktual, mengedukasi, dan bertanggung jawab kepada para audience-nya, salah satunya dengan menyajikan hasil liputan sesuai dengan fakta lapangan saat melakukan aksi demonstrasi yang terjadi di DKI Jakarta pada Tahun 2019-2020. Namun, ketika kebebasan pers serta bentuk tanggung jawab pers terdistorsi oleh tindakan kekerasan yang diterima 
jurnalis oleh oknum anggota kepolisian tersebut, seakan menjadi hambatan utama pada dinamika mereka menyebarkan informasi secara luas. Oknum anggota kepolisian tersebut dilandaskan pada ketidakterimaan mereka pada jurnalis yang seakan hanya meliput aksi kekerasan kepolisian terhadap masa aksi. Tindakan oknum kepolisian tersebut dalam merusak, menghapus, dan kerap menggunakan kekerasan sebagai jalan mereka, tidak sama sekali penulis benarkan, namun adakalanya kita secara seksama melihat pandangan lain dari sebuah isu yang diangkat oleh media atau pers. Alangkah bijaknya jika kita dapat melihat dari dua sisi yang berlawanan, dan masalah pemihakan, dikembalikan lagi kepada penafsiran pembaca. Namun, jangan sampai kita terjebak pada hanya satu sudut pandang saja yang belum tentu juga kebenarannya. Disini penulis mengajak pada pembaca jurnal ini untuk senantiasa lebih bijak lagi dalam membaca sebuah isu yang diangkat oleh pers atau media, dan bukan berarti penulis ada ketidaksukaan pada mesia atau per situ sendiri, tidak sama sekali. Tetapi, tidak ada salahnya juga kita dapat melihat dua sisi yang berbeda, dan kita tidak rugi apapun, malah akan menambah perspektif kita terhadap sebuah isu. Negara demokrasi memang menitik beratkan kepada kebebasan. Diantara corak umum kebebasan yang tergambar di beberapa negara demokrasi tersebut setidaknya adalah kebebasan berpendapat (freedom of expression) dan kebebasan pers (freedom of the press). Kebebsan pers dalam negara demokrasi memang sangat berpengaruh, yang mana hal tersebut dapat menjadi indikator sebuah negara dikatakan demokratis atau tidak. Selain menjadi indikator sebuah negara dapat atau tidaknya dikatakan demokratis, pers juga mempunyai fungsi yang sangat krusial dalam komunikasi politik.

Setidaknya ada 2 sudut pandang yang ditawarkan Voltmer untuk melihat posisi pers, yang pertama sebagai 'marketplace of ideas' dan yang kedua sebagai aktor yang ikut langsung dalam komunikasi politik. Maka dari itu tidak heran jika pers dikatakan sebagai pilar keempat atau the fourth estate dalam negara demokrasi, setalah lembaga eksekutif, legislatif, dan yudikatif.

Dalam perkembangannya, pers menjumpai banyak bentuk, menurut Siebert, Scharm, dan Peterson dalam 4 Teori Pers (Four Theories of The Press), pers dibagi kedalam 4 bentuk, yaitu Pers Otoritarian, Pers Libertarian, Pers Tangggung Jawab Sosial, dan Pers Totalitarian. Pers di Indonesia termasuk kedalam bentuk Pers Tanggung Jawab Sosial karena merujuk pada UU No 4 Tahun 1999 Tentang Pers.

Walaupun kebebasan pers telah dijamin dalam UU No.4 Tahun 1999, jurnalis sebagai sosok penting dalam pers, kerap menjumpai perlakuan tidak menyenangkan yang dilancarkan oleh berbagai pihak, salah satunya pihak kepolisian. Menurut data yang telah dihimpun AJI, tergambar bahwa sepanjang 2019-2020, terdapat 80 kasus kekerasan yang terjadi kepada jurnalis, 34 diantaranya dilakukan oleh pihak kepolisian dan 12 dari 34 kasus tersebut, terjadi saat jurnalis sedang meliput aksi demosntrasi yang terjadi di Jakarta.

Disisi lain, LBH Pers menggambarkan bahwa 2020 adalah tahun dimana pers mendapatkan tindak kekerasan tertinggi dari berbagai elemen di dalam masyarakat, terhitung sejak 1 Januari sampai 10 Desember 2020, terdapat 117 kasus kekerasan terhadap jurnalis yang menurutnya naik secara signifikan sebesar $32 \%$, dibandingkan dengan tahun 2019 yaitu sebanyak 79 kasus. Pihak kepolisian masih mengisi posisi pertama sebagai pihak yang paling sering melakukan tindak kekerasan terhadap jurnalis. 
Kita semua berharap bahwa kebebasan pers di Indonesia, kedepannya makin membaik, dan dari masing-masing pihak pun saling menekan kepentingannya masingmasing, dimana pers harus lebih menaati kode etik jurnalistik, dan pihak kepolisian harus lebih patuh terhadap instruksi Kapolri.

\section{Daftar Pustaka}

Aderia. (2020). "Be Careful and Don't Forget to Pray": Indonesian Female Journalists' Protocol in Dealing with Harassment. Jurnal Komunikasi Indonesia Volume IX, Issue 2, July.

Aliansi Jurnalis Independen. (2021). Data Kekerasan Selama Januari 2019 - Desember 2020. Retrieved from Aliansi Jurnalis Independen Data Kekerasan Terhadap Jurnalis: $\quad$ https://advokasi.aji.or.id/index/datakekerasan $/ 1 . h t m l ? \mathrm{y}=2019 \& \mathrm{~m}=1 \& \mathrm{ye}=2020 \& \mathrm{me}=12 \&$ pelaku$=$ Polisi

BPHN. (n.d.). UU Nomor 9 Tahun 1998. Retrieved 1 20, 2021, from Badan Pembinaan Hukum Nasional : https://www.bphn.go.id/data/documents/98uu009.pdf

Briantika, A. (2019, 12 27). Parade Kekerasan Polisi terhadap Wartawan Sepanjang 2019. Retrieved 1 14, 2021, from Tirto.id: https://tirto.id/parade-kekerasan-polisiterhadap-wartawan-sepanjang-2019-eo6Q

Budiarjo, M. (2009). Dasar-Dasar Ilmu Politik. Jakarta: PT Gramedia Pustaka Utama.

CNN Indonesia. (2020, 10 10). AJI: Kekerasan Polisi ke Jurnalis untuk Sembunyikan Kejahatan. Retrieved 1 14, 2021, from CNN Indonesia: https://www.cnnindonesia.com/nasional/20201010141329-20-556854/ajikekerasan-polisi-ke-jurnalis-untuk-sembunyikan-kejahatan

CNN Indonesia. (2020, 10 9). Polri Buka Suara soal Kekerasan Polisi ke Jurnalis. Retrieved 1 13, 2021, from Indonesia: https://www.cnnindonesia.com/nasional/20201009155713-20-556614/polri-bukasuara-soal-kekerasan-polisi-ke-jurnalis

Dewan Pers. (2020). Profil Lembaga. Retrieved 1 12, 2021, from Dewan Pers: https://dewanpers.or.id/profil/lembaga

ELSAM Lembaga Studi \& Advokasi Masyarakat. (2021). Undang - Undang Nomor 40 Tahun 1999 Tentang Pers. Retrieved from https://referensi.elsam.or.id/2015/08/uunomor-40-tahun-1999-tentang-pers-2/

Firdausi, F. A. (2017, 5 24). Cara Orba Kuasai Berita. Retrieved 1 12, 2021, from Historia: https:/historia.id/politik/articles/cara-orba-kuasai-berita-vXWK4/page/1

Heywood, A. (2004). Political Theory An intrduction Third Edition. London: Palgrave Macmillan.

Hutomo, D. (2019). Pembatasan Berkomentar di Medsos Merampas Hak Kebebasan Berpendapat? Retrieved Hukum Online: https://www.hukumonline.com/klinik/detail/ulasan/lt5d2d75a9b17f0/pembatasanberkomentar-di-medsos-merampas-hak-kebebasan-berpendapat/

Kusumasari, D. (2011, 12). Apakah Polisi Memiliki Kewenangan Memukul Demonstran? Retrieved 1 14, 2021, from Hukum Online: https://www.hukumonline.com/klinik/detail/ulasan/cl4972/polisi-yang-memukuldemonstran/ 
LBH Pers. (2021). Annual Report LBH Pers 2020. Retrieved 1 19, 2021, from LBH Pers: https://lbhpers.org/annual-report-lbh-pers-2020/

Mardatillah, A. (2019, 7 25). Tiga Kesalahan Yang Sering Dilakukan Pers. Retrieved 1 14, 2021, from Hukum Online: https:/www.hukumonline.com/berita/baca/lt5d3898939c3a3/tiga-kesalahan-yangsering-dilakukan-pers?utm_source $=$ dlvr.it\&utm_medium $=$ twitter/

Marijan, K. (2010). Sistem Politik Indonesia. Jakarta: Pranada Media Group.

Muslich, M. (2008). Kekuasaan Media Mengkonstuksi Realitas. BAHASA DAN SENI, Tahun 36, Nomor 2, .

NTB Polri . (n.d.). Perkapolri Nomor 9 Tahun 2008. Retrieved 1 20, 2021, from Kepolisian Negara Republik Indonesia Daerah NTB: https://ntb.polri.go.id/mataram/wpcontent/uploads/2018/02/perkap-no.-9-thn-2008.pdf

Nurmansyah, A. (2019, 12). Polda Sulsel Keluarkan SPDP Sikapi Kasus Kekerasan Terhadap Jurnalis di Makassar. Retrieved 1 14, 2021, from Akurat.co: https://akurat.co/news/id-898484-read-polda-sulsel-keluarkan-spdp-sikapi-kasuskekerasan-terhadap-jurnalis-di-makassar

Pirtaningras, A. R. (2017). KajianFreedom of Speech and Expression dalam Perlindungan Hukum terhadap Demonstran di Indonesia. Lex Scientia Law Review, Volume 1 No. 1 .

Saptohadi, S. (2011). Pasang Surut Kebebasan Pers di Indonesia. Jurnal Dinamika Hukum Vol. 11 No.1, 128.

Triyono, D. A. (2013). The Four Press Media Theories: Authoritharianism Media Theory, Libertartianism Media Theory, Social Responsibility Media Theory, and Totalitarian Media Theory. Ragam Jurnal Pengembangan Humaniora Vol. 13 No. 3.

Wardah, F. (2020, Januari 11). LBH Pers: Polisi Paling Banyak Lakukan Kekerasan terhadap Wartawan Selama 2019. Retrieved from VOA Indonesia: https://www.voaindonesia.com/a/lbh-pers-polisi-paling-banyak-lakukan-kekerasanterhadap-wartawan-selama-2019/5244121.html

Buku:

Budiarjo, M. (2009). Dasar-Dasar Ilmu Politik . Jakarta: PT Gramedia Pustaka Utama.

Heywood, A. (2004). Political Theory An intrduction Third Edition. London: Palgrave Macmillan.

Marijan, K. (2010). Sistem Politik Indonesia. Jakarta: Pranada Media Group.

Nair, B. M. (2011). An Introduction To Political Communication Fifth Edition. New York: Routledge.

Artikel Daring:

Aliansi Jurnalis Independen. (2021). Data Kekerasan Selama Januari 2019 - Desember 2020. Diambil kembali dari Aliansi Jurnalis Independen Data Kekerasan Terhadap Jurnalis: https://advokasi.aji.or.id/index/datakekerasan $/ 1 . h t m l ? y=2019 \& \mathrm{~m}=1 \& \mathrm{ye}=2020 \& \mathrm{me}=12 \&$ pelaku $=$ Polisi

Briantika, A. (2019, 12 27). Parade Kekerasan Polisi terhadap Wartawan Sepanjang 2019. Retrieved 1 14, 2021, from Tirto.id: https://tirto.id/parade-kekerasan-polisiterhadap-wartawan-sepanjang-2019-eo6Q 
CNN Indonesia. (2020, 10 10). AJI: Kekerasan Polisi ke Jurnalis untuk Sembunyikan Kejahatan. Dipetik 1 14, 2021, dari CNN Indonesia: https://www.cnnindonesia.com/nasional/20201010141329-20-556854/ajikekerasan-polisi-ke-jurnalis-untuk-sembunyikan-kejahatan

CNN Indonesia. (2020, 10 9). Polri Buka Suara soal Kekerasan Polisi ke Jurnalis. Dipetik $1 \quad 13, \quad 2021, \quad$ dari $\quad$ CNN Indonesia: https://www.cnnindonesia.com/nasional/20201009155713-20-556614/polri-bukasuara-soal-kekerasan-polisi-ke-jurnalis

Dewan Pers. (2020). Profil Lembaga. Dipetik 1 12, 2021, dari Dewan Pers: https://dewanpers.or.id/profil/lembaga

Firdausi, F. A. (2017, 5 24). Cara Orba Kuasai Berita. Dipetik 1 12, 2021, dari Historia: https://historia.id/politik/articles/cara-orba-kuasai-berita-vXWK4/page/1

Halim, D. (2019, 10 07). Arogansi Polisi Dinilai Bisa Turunkan Kepercayaan Publik pada Polri. Dipetik 07 28, 2021, dari Kompas.com: https://nasional.kompas.com/read/2019/10/09/08593951/arogansi-polisi-dinilaibisa-turunkan-kepercayaan-publik-pada-polri?page=all

Hutomo, D. (2019). Pembatasan Berkomentar di Medsos Merampas Hak Kebebasan Berpendapat? Diambil kembali dari Hukum Online: https://www.hukumonline.com/klinik/detail/ulasan/lt5d2d75a9b17fo/pembatasanberkomentar-di-medsos-merampas-hak-kebebasan-berpendapat/

Kusumasari, D. (2011, 12). Apakah Polisi Memiliki Kewenangan Memukul Demonstran? Dipetik 1 14, 2021, dari Hukum Online: https://www.hukumonline.com/klinik/detail/ulasan/cl4972/polisi-yang-memukuldemonstran/

Mardatillah, A. (2019, 7 25). Tiga Kesalahan Yang Sering Dilakukan Pers. Dipetik 1 14, 2021, dari Hukum Online: https://www.hukumonline.com/berita/baca/lt5d3898939c3a3/tiga-kesalahan-yangsering-dilakukan-pers? utm_source=dlvr.it\&utm_medium=twitter/

Nurmansyah, A. (2019, 12). Polda Sulsel Keluarkān SPDP Sikapi Kasus Kekerasan Terhadap Jurnalis di Makassar. Dipetik 1 14, 2021, dari Akurat.co: https://akurat.co/news/id-898484-read-polda-sulsel-keluarkan-spdp-sikapi-kasuskekerasan-terhadap-jurnalis-di-makassar

Tempo. (2019, 12 23). AJI: Musuh Kebebasan Pers Adalah Polisi. Dipetik 07 28, 2021, dari Tempo.co: https://nasional.tempo.co/read/1287069/aji-musuh-kebebasan-persadalah-polisi

Wardah, F. (2020, Januari 11). LBH Pers: Polisi Paling Banyak Lakukan Kekerasan terhadap Wartawan Selama 2019. Diambil kembali dari VOA Indonesia: https://www.voaindonesia.com/a/lbh-pers-polisi-paling-banyak-lakukan-kekerasanterhadap-wartawan-selama-2019/5244121.html

Artikel dari Jurnal Cetak:

Aderia. (2020). "Be Careful and Don't Forget to Pray": Indonesian Female Journalists' Protocol in Dealing with Harassment. Jurnal Komunikasi Indonesia Volume IX, Issue 2, July. 
BPHN. (t.thn.). UU Nomor 9 Tahun 1998. Dipetik 1 20, 2021, dari Badan Pembinaan Hukum Nasional: https://www.bphn.go.id/data/documents/98uu009.pdf

Muslich, M. (2008). Kekuasaan Media Mengkonstuksi Realitas. BAHASA DAN SENI, Tahun 36, Nomor 2,

Pirtaningras, A. R. (2017). KajianFreedom of Speech and Expression dalam Perlindungan Hukum terhadap Demonstran di Indonesia. Lex Scientia Law Review, Volume 1 No. 1 .

Saptohadi, S. (2011). Pasang Surut Kebebasan Pers di Indonesia. Jurnal Dinamika Hukum Vol. 11 No.1, 128.

Triyono, D. A. (2013). The Four Press Media Theories: Authoritharianism Media Theory, Libertartianism Media Theory, Social Responsibility Media Theory, and Totalitarian Media Theory. Ragam Jurnal Pengembangan Humaniora Vol. 13 No. 3.

Dokumen Internet:

ELSAM Lembaga Studi \& Advokasi Masyarakat. (2021). Undang - Undang Nomor 40 Tahun 1999 Tentang Pers. Diambil kembali dari https://referensi.elsam.or.id/2015/08/uu-nomor-40-tahun-1999-tentang-pers-2/

LBH Pers. (2021). Annual Report LBH Pers 2020. Dipetik 1 19, 2021, dari LBH Pers: https://lbhpers.org/annual-report-lbh-pers-2020/

.NTB Polri. (t.thn.). Perkapolri Nomor 9 Tahun 2008. Dipetik 1 20, 2021, dari Kepolisian Negara Republik Indonesia Daerah NTB: https://ntb.polri.go.id/mataram/wpcontent/uploads/2018/02/perkap-no.-9-thn-2008.pdf 